\title{
An Application of WEAP Model in Water Resources Management Considering the Environmental Scenarios and Economic Assessment Case Study: Hirmand Catchment
}

\author{
Ali Sardar Shahraki ${ }^{1}$, Javad Shahraki ${ }^{2}$ \& Seyed Arman Hashemi Monfared ${ }^{3}$ \\ ${ }^{1} \mathrm{PhD}$ student, Department of Agricultural Economics, University of Sistan and Baluchestan, Iran \\ ${ }^{2}$ Associate Professor, Department of Agricultural Economics, University of Sistan and Baluchestan, Iran \\ ${ }^{3}$ Assistant Professor, Department of Civil Engineering, University of Sistan and Baluchestan, Iran \\ Correspondence: Ali Sardar Shahraki, Department of Agricultural Economics, University of Sistan and \\ Baluchestan, Iran. Tel: 98-54-3342-7594. E-mail: E-mail: A.Shahraki65@Pgs.usb.ac.ir
}

Received: January 17, 2016

Accepted: January 28, 2016

Online Published: March 13, 2016

doi:10.5539/mas.v10n5p49

URL: http://dx.doi.org/10.5539/mas.v10n5p49

\begin{abstract}
Hirmand catchment is one of the important trans boundary catchment in Iran. Sistan people living in south east Iran related to this catchment. Meanwhile drought of the last two decades, due to dust storms jeopardized the Human health. Also, causing destroyed vegetation cover and animal habitat in region. The first objective of the present study is water resources management under environmental scenarios using the WEAP model in Hirmand catchment. In study, dust stabilization and animal-plant sustainable ecosystem scenarios have been applied. The second objective is economic assessment of defined scenarios. According to the results, average total demand in dust stabilization and animal-plant sustainable ecosystem scenarios increased about 238 and 231 million cubic meters compared to the current account, respectively. Also, unmet demand compared to the current account increased 193 and 200 million cubic meters, approximately. According to the economic assessment calculations, benefit in dust stabilization scenario 160 milliards rials and in animal-plant sustainable ecosystem scenario 209 milliards rials decreased in agriculture sector. Therefore, despite the decline in benefit, in policy making and water resources management should be special attention to protect the environment wetlands.
\end{abstract}

Keywords: water resources management, stabilization dust, sustainable ecosystem, hirmand catchment

\section{Introduction}

Evaluating the impacts of ecosystem degradation, from rehabilitation to society growth in the region, must include an understanding of the region and particularly those agents that are responsible for the features of an ecosystem in a region. In the case of wetlands, there is a general appreciation for the superior role of environmental and physical attributes (Wilcox, 1995).

Meanwhile, dust storms, as a main source of mineral aerosols, are natural dangers that affect ecosystems, climate, weather, human health. This phenomenon mostly occurs in the arid and semi-arid regions over the globe (Rashki et al, 2013; Prospero et al., 2002).

Wetland is an important zone between water and land with plenty biodiversity and numerous function, but ecological environment is vulnerable (Kent, 1996; Klemov, 1998; Jiang et al., 1998; Whigham, 1999; Xu et al., 1999) and complete dependence on the water. Hence, water must be guaranteed for all demands, especially to meet the basic human needs in the societies who have been disadvantaged for so long. Furthermore, water should not be simply released to meet the increased demands from industry, agriculture, services and other productive demands but should also satisfy the requirements of aquatic ecosystems and the ecological reserve (Lévite et al. 2003).

The Sistan region (in Iran) has been considered as a major dust source in southwest Asia (Middleton, 1986; Prospero et al., 2002; Léon and Legrand, 2003; Goudie et al., 2013). Hirmand catchment in Sistan region is located close to the Iranian border with Pakistan and Afghanistan, in the southeastern part of Iran (See Fig 1). There are five cities with 1050 villages and near to 400000 thousands population in Sistan region. The climate of the region is approximately arid, with an annual average of precipitation that is $60 \mathrm{~mm}$ occurring mainly in 
winter while the mean of evaporation exceeding $4000 \mathrm{~mm} \mathrm{yr}^{-1}$ as a result of high temperatures. Hirmand River (sometimes called Helmand River) is considered as a source of life. This river emanates from the Afghanistan's Helmand province in Baba-Yaghma Mountain and comes across the border of Iran (Sistan region) and divides into two branches (Paryan and Sistan) and eventually releases into the Hamoun wetland. Chahnimeh reservoirs are one of the other important sources of water in Sistan region. Since the main occupation of the region is agriculture, therefore considering the reservoirs can play an important role for the life of these people (Rashki et al, 2012). Dust storm in sistan region affect on air quality, Human health, ecosystem and the environment. This phenomenon commonly known as the "120-day wind", which causes repeated dust especially during June August (Rashki et al, 2013). Position of Hirmand catchment in Iran and Afghanistan is in shown Fig (1).

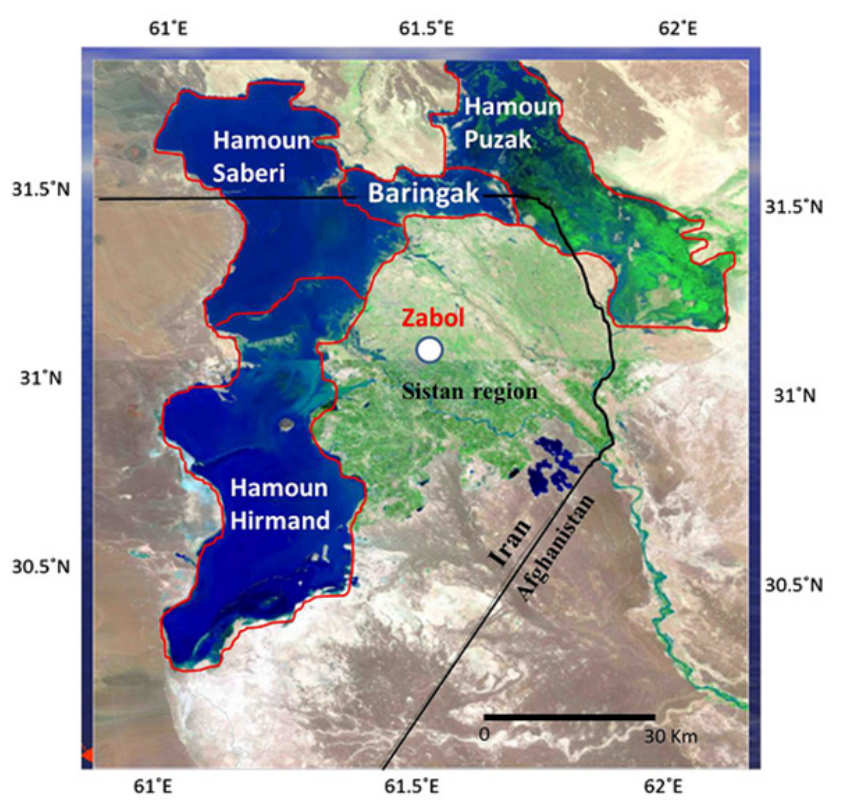

Figure 1. Position of Hirmand catchment in Iran and Afghanistan (UNEP, 2006)

Water is a finite resource in Sistan region and also it is a very important economic and social resource for the people living in this region. It is essential to explore on how the future water resources of the catchment will look like in order to better plan for a sustainable social-economic development. There is a wide variety of users of water with apparently different interests, influences and objectives. Drinking water supply source of one million people in the Sistan region of the Hirmand River. Farming is the main occupation of the Sistan people which is highly influenced by the Hirmand River. Hamoun Lake (e.g. Hamoun Saburi, Hamoun Puzak) is the largest freshwater ecosystem in the Iranian plateau, and one of the first wetlands identified in the Ramsar convention that its conservation is important. Investigate the effects water development projects envisaged by the government in the Sistan region, on agriculture and wetlands are very important.

Models such as River Basin Simulation Model (RIBASIM), Water Balance Model (WBalMo), MODSIM, MIKE Basin, Multi-Sectoral, Integrated and Operational Decision Support System (MULINO-DSS), Water Evaluation and Planning System (WEAP) were used for planning purposes in the basins, water quality and sedimentation transport, river flow routing, evaluation alternative water allocation policies and water demand analysis (Mugatsia 2010).

WEAP is a model that is used for the simulation of water resource system in important studies and in many cases is the interest of researchers. Applications of WEAP model can be seen in researches of Hollermann et al. (2010), Vonk et al. (2014), Li et al. (2015), Dimova et al. (2014), Yaqob et al. (2015), Condom et al. (2011), Choi et al. (2010) and Mounir et al. (2011).

In the present study, integrated water resources management considering the environmental scenarios is investigated in Hirmand catchment. Hence, in the first step, the study area simulated by WEAP model. In the second step, Economic impact of defined scenarios calculated. 


\section{Materials and Methods}

\subsection{WEAP Model}

WEAP Model developed by the Stockholm Environment Institute is based on the water balance and it requires the agricultural, domestic and environmental demands in one side and on the other side some factors such as sources of supply (e.g. rivers, reservoirs and groundwater), withdrawals, water demands, water quality, economic assessment and ecosystem requirements are important. Accordingly, we can have a comprehensive tool for planning and policy analysis. The most important feature of this tool is its application for all single watersheds, complex trans-boundary river basin system or the agricultural and municipal systems. This model has great ability to simulate a broad range of engineered and natural components of the systems, including water demand analyses, water conservation, hydropower generation, water quality and pollution tracking, water allocation priorities, vulnerability assessments, rainfall runoff, base flow and groundwater recharge from precipitation, ecosystem requirements and reservoir operations (Sieber et al. 2005).

\subsection{Economic Assessment Model}

In this step, according to the results obtained of the WEAP model, the effects of environmental scenarios in the agricultural sector will be calculated. Economic evaluation model in study is:

$$
\operatorname{Max} \quad \tilde{\beta}_{j}=\sum_{j=1}^{n} \sum_{i=1}^{m} P c p_{j i} \cdot Y a_{j i} \cdot A F_{i j}-\sum_{j=1}^{n} \sum_{i=1}^{m} \sum_{k=1}^{q} P c o_{j i k} \cdot X_{j i k} \cdot A F_{i j}
$$

\section{Subject to:}

\section{Constraints of WEAP model}

$P c p_{j i}$ : The price of product $i$ in area $j, Y a_{j i}:$ the yield of Product $i$ in area $j, A F_{i j}:$ the Cultivation area of Product $i$ in area $j, P c o_{j i k}$ : the price of input $k$ for the product $i$ in the area $j,: X_{j i k}$ : The amount of inputs $k$ for the product $i$ in the area $j$. The steps of the simulation are shown in Figure 2:

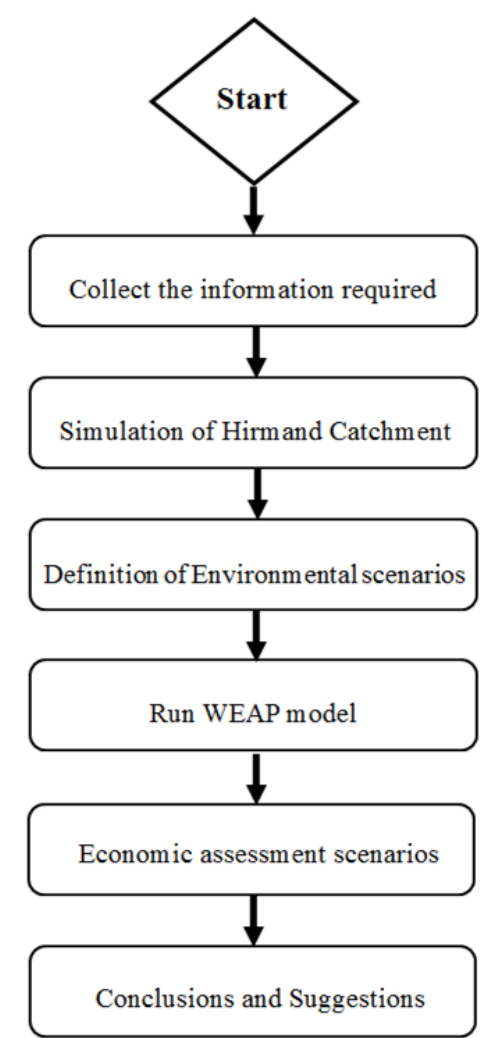

Figure 2. Schematic of the Simulation methodology 
Some scenarios should be defined in the study area for the simulation of water resources. The selected scenarios of water demand management in this study are as follows:

Scenario 1 (Current account): This scenario is there by default (Reference scenario) and represents the current status with past management and indeed is used as the basis for comparison with other scenarios. In other words, if Hirmand catchment considers to be managed under the current situation and past policies, what is the water resource situation of the catchment by 2030 .

Scenario 2 (Dust stabilization): Soil erosion greatest in the Sistan region is during June - August. Therefore, these 5 months as selected the critical months. Water requirement for dust stabilization is sum of evaporation from soil surface and the amount of water to soil saturate. According to reports, in Sistan region, the water evaporation in 5 critical months is 5925 cubic meters and the amount of water requirements for saturated soil is 50 cubic meters per hectare (Reports of the department of environment, 2015). Also, 50000 hectare of wetlands (Fig 3) specified as center of crisis dust, that this study, this surface considered.

Scenario 3 (Animal-plant sustainable ecosystem): of the 3 wetlands in the Sistan region, Hamoun Saberi is the first priority of dewatering based on animal-plant sustainable ecosystem. (Reports of the department of environment, 2015). Total area of Hamoun Saberi is 40,000 hectares. Therefore, according to water condition in sistan region, just $20 \%$ of the total area $(8,000$ hectares) selected in study. According to reports, water required for this area is 36450 cubic meters per hectare.
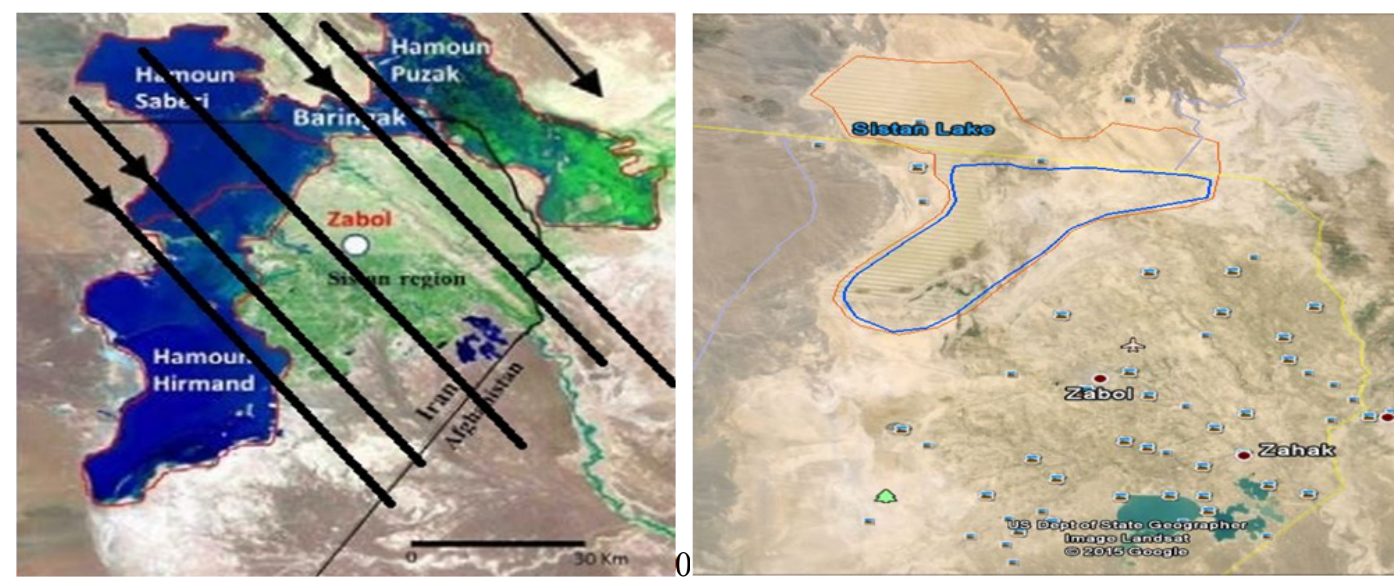

Figure 3. Map of the study area showing the Hirmand catchment

Tales 1 shows the sites specifications of water demands and supplies in Sistan region.

Table 1. Sites Specifications of demand and supply water In the Sistan region

\begin{tabular}{|c|c|c|c|}
\hline Reservoir $_{1}$ & $\begin{array}{l}\text { Inflow of Sistan River Enters To this reservoir. } \\
\text { Total storage is } 660 \mathrm{MCM} \text { and dead storage is } \\
\text { approximately } 320 \mathrm{MCM} \text { and is the main source } \\
\text { of water for agriculture, Urban water and wetlands } \\
\text { demands. }\end{array}$ & $\begin{array}{l}\text { Sistan\&Paryan } \\
\text { River }\end{array}$ & $\begin{array}{l}\text { Initially Sistan river flows enter to reservoir }{ }_{1} \text { and } \\
\text { the surplus water for } \mathrm{Agr}_{1} \text { and } \mathrm{Agr}_{2} \text { demands will be } \\
\text { transferred, Finally, Sistan River release to Hamoun } \\
\text { wetland. Paryan River provides } \mathrm{Agr}_{3} \text { water } \\
\text { demand. }\end{array}$ \\
\hline Reservoir $_{2}$ & $\begin{array}{l}\text { Surplus water of reservoir }{ }_{1} \text { enters to this reservoir. } \\
\text { Total storage is } 820 \mathrm{MCM} \text { and the inactive zone is } \\
\text { approximately } 200 \mathrm{MCM} \text {. }\end{array}$ & City $_{6}$ & $\begin{array}{l}\text { Population of this city is } 3,300 \text { people; } \\
\text { Annual water use rate is } 46.01 \mathrm{~m}^{3} / \text { person }\end{array}$ \\
\hline City $_{1}$ & $\begin{array}{l}\text { Population of this city is } 600,000 \text { people; } \\
\text { Annual water use rate is } 55.56 \mathrm{~m}^{3} / \text { person }\end{array}$ & Rural & $\begin{array}{l}\text { Population of this city is } 266,000 \text { people; } \\
\text { Annual water use rate is } 54.75 \mathrm{~m}^{3} / \text { person }\end{array}$ \\
\hline $\mathrm{City}_{2}$ & $\begin{array}{l}\text { Population of this city is } 142,000 \text { people; } \\
\text { Annual water use rate is } 58.02 \mathrm{~m}^{3} / \text { person }\end{array}$ & Agr $_{1}$ & $\begin{array}{l}\text { Cultivated area is about } 49,000 \text { ha; } \\
\text { Water use rate }{ }^{\text {b }} \text { is } 8750 \mathrm{~m}^{3} / \mathrm{ha}\end{array}$ \\
\hline $\mathrm{City}_{3}$ & $\begin{array}{l}\text { Population of this city is } 14,000 \text { people; } \\
\text { Annual water use rate is } 53.34 \mathrm{~m}^{3} / \text { person }\end{array}$ & $\mathbf{A g r}_{2}$ & $\begin{array}{l}\text { Cultivated area is about } 54,000 \text { ha; } \\
\text { Water use rate }{ }^{\mathrm{b}} \text { is } 8450 \mathrm{~m}^{3} / \mathrm{ha}\end{array}$ \\
\hline City $_{4}$ & Population of this city is 6,700 people; & $\mathbf{A g r}_{3}$ & Cultivated area is about $32,000 \mathrm{ha}$; \\
\hline
\end{tabular}




\begin{tabular}{|c|c|c|c|}
\hline & Annual water use rate is $57.37 \mathrm{~m}^{3} /$ person & & Water use rate ${ }^{b}$ is $7950 \mathrm{~m}^{3} / \mathrm{ha}$ \\
\hline City $_{5}$ & $\begin{array}{l}\text { Population of this city is } 72,000 \text { people; } \\
\text { Annual water use rate is } 47.97 \mathrm{~m}^{3} / \text { person }\end{array}$ & Lake & $\begin{array}{l}\text { Total area is about } 400,000 \text { ha, } \\
\text { Water rights approval }^{\mathrm{c}} 60 \mathrm{MCM} / \text { Year }\end{array}$ \\
\hline
\end{tabular}

${ }^{\mathrm{a}}$ Million cubic meters;

${ }^{b}$ This rate is obtained according to the cropping pattern dominant in each area;

c This water rights determined for 2,500 hectares of Hamoun wetlands.

In Sistan region are 3 sectors of agricultural, 7 sectors of drinking water (6 urban and 1 rural) and Hamoun wetlands sector. The priority of water allocation in this region is respectively belonging to drinking, agriculture and wetlands sectors.

\section{Results and Discussion}

Table (2) shows WEAP model results separately average total demand and average unmet demand for each year (between 2015-2030) for different sectors under 3 scenarios. According to the results of $\mathrm{SC}_{2}$ and $\mathrm{SC}_{3}$, demands of agriculture and domestic sectors will not change. Average total demand for each year (between 2015-2030) in $\mathrm{SC}_{2}$ and $\mathrm{SC}_{3}$ increased to approximately 1530 and 1522 million cubic meters. Also, unmet demand for each year (between 2015-2030) increased to approximately 704 and 711 million cubic meters. Therefore, in environmental scenarios $\left(\mathrm{SC}_{1}, \mathrm{SC}_{2}\right)$ amount unmet demand greatly increased.

Hence, unmet demand the totally about 193 million cubic meters in the $\mathrm{SC}_{1}$ and about 200 million cubic meters in the $\mathrm{SC}_{2}$ of water increased compared to the reference scenario.

Recognizing the importance of drinking water allocation in the region and giving first priority to this sector, its demand fully was estimated (100\%).

Table 2. The output WEAP model, in the different sectors, under three reference and virtual water scenarios.

\begin{tabular}{llllllll}
\hline Scenarios & & $\mathbf{S C}_{\mathbf{1}}$ & $\mathbf{S C}_{\mathbf{2}}$ & $\mathbf{S C}_{\mathbf{3}}$ & $\mathbf{S C}_{\mathbf{1}}$ & $\mathbf{S C}_{\mathbf{2}}$ & $\mathbf{S C}_{\mathbf{3}}$ \\
\hline Type of demand & & $\mathbf{A}$ & & & $\mathbf{B}$ & & \\
Agriculture Sector & $\mathrm{Agr}_{1}$ & 428.75 & 428.75 & 428.75 & 189.04 & 234.25 & 246.04 \\
& $\mathrm{Agr}_{2}$ & 471.56 & 471.56 & 471.56 & 207.69 & 257.21 & 270.2 \\
& $\mathrm{Agr}_{3}$ & 279.44 & 279.44 & 279.44 & 79.4 & 79.41 & 79.41 \\
Drinking sector & $\mathrm{City}_{1}$ & 26 & 26 & 26 & 0 & 0 & 0 \\
& $\mathrm{City}_{2}$ & 9.28 & 9.28 & 9.28 & 0 & 0 & 0 \\
& $\mathrm{City}_{3}$ & 0.86 & 0.86 & 0.86 & 0 & 0 & 0 \\
& $\mathrm{City}_{4}$ & 0.42 & 0.42 & 0.42 & 0 & 0 & 0 \\
& $\mathrm{City}_{5}$ & 0.39 & 0.39 & 0.39 & 0 & 0 & 0 \\
Environmental sector & $\mathrm{City}_{6}$ & 0.17 & 0.17 & 0.17 & 0 & 0 & 0 \\
& $\mathrm{Rural}$ & 14.43 & 14.43 & 14.43 & 0 & 0 & 0 \\
& Lake & 60 & 298.75 & 291.6 & 34.86 & 133.18 & 115.44 \\
& & $\mathbf{1 2 9 1 . 3}$ & $\mathbf{1 5 3 0 . 0 5}$ & $\mathbf{1 5 2 2 . 9}$ & $\mathbf{5 1 0 . 9 9}$ & $\mathbf{7 0 4 . 5 5}$ & $\mathbf{7 1 1 . 0 9}$ \\
\hline Aum & & & & & &
\end{tabular}

Amounts are in million cubic meters.

A: Average total demand for each year (between 2015-2030) separately for different sectors under 2 reference and virtual water scenario's.

B: Average unmet demand for each year (between 2015-2030) separately for different sectors under 2 reference and virtual scenario's.

Figure 1 shows the percent of met demand for different sectors, on average under reference scenario $\left(\mathrm{SC}_{1}\right)$ and environmental scenarios $\left(\mathrm{SC}_{2}, \mathrm{SC}_{3}\right)$ between 2015-2030. 


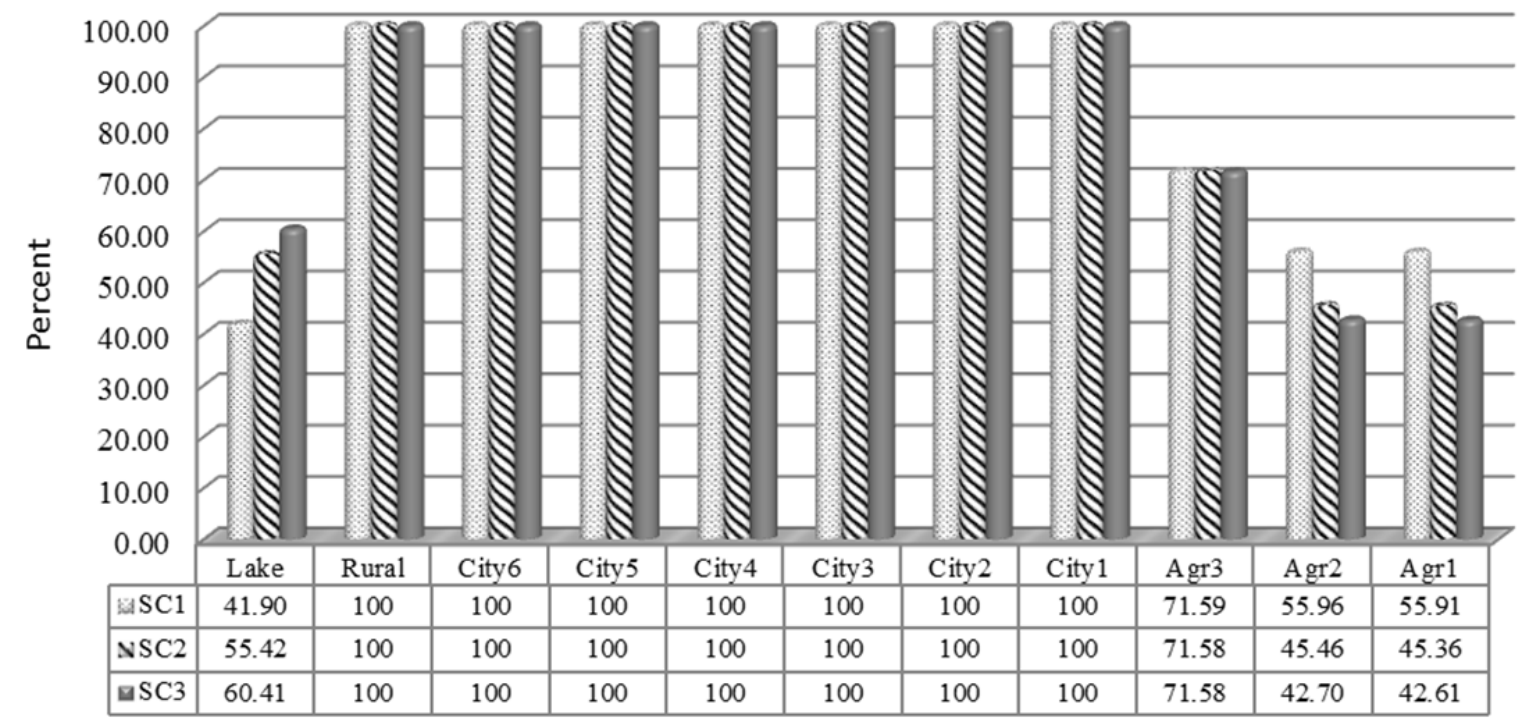

Figure 4. Comparing the percent of met demand for different sections under environmental scenarios (SC2, SC3) and reference scenarios $\left(\mathrm{SC}_{1}\right)$, an average, between 2015-2030

According to the results (Fig 4) compared to the reference scenario, met demand on average $10.5 \%, 10.5 \%$ in $\mathrm{SC}_{2}, 13.3 \%, 13.2 \%$ in $\mathrm{SC}_{3}$ decreased for $\mathrm{Agr}_{1}, \mathrm{Agr}_{2}$, respectively, between 2015-2030. Amount met demand for drinking sector was $100 \%$ in both scenarios. Also, increase in the amount of met demand in the environmental sector (Lake), in $\mathrm{SC}_{2}$ toward the references scenario is $13.5 \%$ and in $\mathrm{SC} 3$ is $18.5 \%$. Table (3) shows the economic benefit resulting from the application of $\mathrm{SC}_{2}$ and $\mathrm{SC}_{3}$ in the agricultural sector.

Table 3. Economic benefit resulting from the application of $\mathrm{SC}_{2}$ and $\mathrm{SC}_{3}$ in the agricultural sector (unit: milliard rails)

\begin{tabular}{lllll}
\hline & $\mathrm{Agr}_{1}$ & $\mathrm{Agr}_{2}$ & $\mathrm{Agr}_{3}$ & Total \\
\cline { 2 - 5 } $\mathrm{SC}_{1}$ & 410.74 & 450.8 & 330.11 & 1200.66 \\
$\mathrm{SC}_{2}$ & 330.87 & 370.21 & 330.11 & 1040.19 \\
$\mathrm{SC}_{3}$ & 310.82 & 340.95 & 33011 & 990.88 \\
\hline
\end{tabular}

Based on the results (table 3 ) compared to the reference scenario, economic benefit 160.47 milliard rails in $\mathrm{SC}_{2}$ and 209.78 milliard rails decreased.

\section{Suggestions}

In this study, Hirmand catchment was simulated by using WEAP model in order to assess the implementation effects of the concept of environmental scenarios and compare them with the current account. The results of three main scenarios were analyzed. According to the results the following suggestions are recommended:

Since the wetlands play a vital role in the ecological conditions in this region, its damages to it, in addition to economic problems, will lead to social problems. According to the results, in the $\mathrm{SC}_{2}$ and $\mathrm{SC}_{3}$, more water demand provided for the environmental sector (Lake) and damages to this sector will be reduced. Hence, to protect wetland ecosystems the implementation of this scenario needs to special attention of relevant organizations.

\section{References}

Choi S, Lee, D. R., Moon, J. W., \& Kang, S. K. (2010). Application of K-WEAP (Korea-Integrated Water Resources Evaluation and Planning Model). Journal of Korea Water Resources Association, 43(7), 625-633.

Condom, T., Escobar, M., Purkey, D., Pouget, J. C., Suarez, W., Ramos, C., Apaestegui, J., Zapata, M., Gomez, J., \& Vergara, W. (2011). Modeling the hydrologic role of glaciers within a Water Evaluation and Planning System (WEAP): a case study in the Rio Santa watershed (Peru). Hydrol. Earth Syst. Sci. Discuss, 8(1), 
869-916.

Dimova, G., Tzanov, E., Ninov, P., Ribarova, M., \& Kossida, M. (2014). Complementary use of the WEAP model to underpin the development of SEEAW physical water use and supply tables. Procedia Engineering, $70,563-572$.

Goudie, A. S. (2013). Desert dust and human health disorders. Environ. Intern., 63, 101-113.

Hollermann, B., Giertz, S., \& Diekkrüger, B. (2010). Balancing Future Water Availability and Demand Using the WEAP 'Water Evaluation and Planning' System. Water Resour Manage, 24(13), 3591-3613.

Jiang, M. K., Zhou, Z. J., \& He, S. N. (1998). Protection and sustainable utilization of wetland biodiversity in China. Journal of Northeast Normal University, 2, 79-84.

Kent, D. M. (1996). Defining Wetlands', in D. M. Kent (ed), Applied Wetlands Science and Technology, Lewis Publishers, Boca Raton, FL.

Klemov, K. M. (1998). Wetland Mapping, in S. K. Majumdar, E. W. Miller and F. J. Brenner (Eds), Ecology of Wetlands and Associated Systems. The Pennsylvania Academy of Science.

Léon, J. F., \& Legrand, M. (2003). MineraldustsourcesinthesurroundingsofthenorthIndian Ocean. Geophys. Res. Lett., 30(6), 1309.

Lévite, H., Sally, H., \& Cour, J. (2003). Testing water demand management scenarios in a water-stressed basin in South Africa: Application of the WEAP model. Physics and Chemistry of the Earth, 28(20 \& 27), 779-786.

Li, X. E., Zhao, Y., Shi, C., Sha, J., Wang, Z. L., \& Wang, Y. (2015). Application of Water Evaluation and Planning (WEAP) model for water resources management strategy estimation in coastal Binhai New Area, China. Ocean \& Coastal Management, 106, 97-109.

Middleton, N. J. (1986). Dust storms in the Middle East. J. Arid Environ, 10, 83-96.

Mounir, Z. M., Ma, C. M., \& Amadou, I. (2011). Application of water evaluation and planning (WEAP): A model to assess future water demands in the Niger river (in Niger republic). Modern Applied Science, 5(1), $38-49$.

Mugatsia, E. (2010). Simulation and scenario analysis of water resources management in Perkerra catchment using WEAP model. MS Thesis, Department of civil and structural engineering, The University of Moi, Kenya.

Prospero, J. M., Ginoux, P., Torres, O., Nicholson, S. E., Gill, T. E. (2002). Environmental characterization of global sources of atmospheric soil dust identified with the Nimbus 7 total ozone mapping spectrometer absorbing aerosol product. Rev. Geophys, 40, 2-31.

Rashki, A., Kaskaoutis, D. G., Rautenbach, C. J. Dew, Eriksson, P. G., Qiang, M., \& Gupta. P. (2012). Dust storms and their horizontal dust loading in the Sistan region, Iran. Aeolian Research, 5, 51-62.

Rashki, D. G., Kaskaoutis, A. S., \& Goudie, R. A. K. (2013). Dryness of ephemeral lakes and consequences for dust activity: The case of the Hamoun drainage basin, southeastern Iran. Science of the Total Environment, 463-464(2013), 552-564.

Reports of the Department of Environment. (2015). Sistan and Baluchestan Province, Iran.

Sieber, J., Chris, S. D., \& Huber-Lee, A. (2005). WEAP (Water Evaluation and Planning System), User guide for WEAP $_{21}$. Stockholm Environment Institute. U.S. Center. USA.

United Nations Environment Programme (UNEP). History of environmental change inthe Sistan basin based on satellite image analysis: $1976-2005,200660$.

Vonk, E., Xu, Y. P., Booij, M. J., Zhang, X., \& Augustijn, D. C. M. (2014). Adapting Multi reservoir Operation to Shifting Patterns of Water Supply and Demand a Case Study for the Xinanjiang-Fuchunjiang Reservoir Cascade. Water Resour Manage, 28(3), 625-643.

Whigham, D. F. (1999). Ecological issues related to wetland preservation, restoration, creation and assessment. Sci. Total Environ, 240, 31-40.

Wilcox, D. A. (1995). Wetland and aquatic macrophytes as indicators of anthropogenic hydrologic disturbance. Natural Areas Journal, 15, 240-248.

Xu, H. Z., \& Chen, Q. (1999). Nature reservation and biodiversity in wetlands. Environment Herald, 5, 42-43.

Yaqob, Y., Al-Sa 'Ed, R., Sorial, G., \& Sudian, M. (2015). Simulation of transboundary wastewater resource 
management scenarios in the Wadi Zomer watershed, using a WEAP model. International Journal of Basic and Applied Sciences, 4(1), 27-35.

\section{Copyrights}

Copyright for this article is retained by the author(s), with first publication rights granted to the journal.

This is an open-access article distributed under the terms and conditions of the Creative Commons Attribution license (http://creativecommons.org/licenses/by/3.0/). 